\title{
Pauline Westerman, Outsourcing the Law: A Philosophical Perspective on Regulation
}

\author{
Irawan Sewandono
}

Pauline Westerman, Outsourcing the Law: A Philosophical Perspective on Regulation (Cheltenham: Edgar Elgar), 2018, ISBN: 978-1-78536-501-0, 208 p.

Sinds de jaren negentig is geconditioneerde zelfregulering ten grondslag gelegd aan veel wetten. Dit sturingsmodel duidt de Groningse rechtsfilosoof Pauline Westerman aan met de in Nederland niet gangbare term 'Outsourcing the Law'. Zij heeft haar boek niet met de blik van de wetgever geschreven maar met die van de burger. Zij vraagt zich af hoe het ideaal van de rechtsstaat met zijn traditionele waarborgen van volksvertegenwoordiging en machtenscheiding nog kan worden teruggevonden in de instrumentele wereld van een Rule of Outsourced Law. Wat is nog overgebleven van de invloed van de burger en de rol van de rechterlijke macht? Hoe kan de nu ontstane situatie worden verbeterd?

Westerman schetst in de inleidende paragrafen van de belangrijkste hoofdstukken toch nog even de relevante kenmerken van traditionele wetgeving en rechtspraak. Deze wetten bevatten voornamelijk gedragsregels en zelden alleen maar een te bereiken resultaat (ought-to-do versus ought-to-be, p. 31), zijn een in het algemeen belang bereikt evenwichtig compromis tussen de verschillende betrokken doelen en diverse belangen (p. 43), alleen al hun algemeen verbindende aard en algemene aanvaarding zijn meer dan voldoende redenen voor de naleving en handhaving (p. 45), hun vaststelling geschiedt in samenwerking met een vertegenwoordigend lichaam waarvan de leden om de vier jaar door de burgers worden gekozen (p. 76). De rechter beslecht aan hem voorgelegde geschillen aan de hand van de toepasselijke wetsbepalingen. Alleen als deze onduidelijk zijn, grijpt hij terug op de onderliggende bedoeling van de wetgever of het maatschappelijk wenselijke resultaat (p. 105).

Bij uitbesteding van regelgeving schrijft de parlementaire wetgever niet meer precies voor wat de burgers moeten doen of nalaten. In plaats daarvan maakt hij een drieslag. Eerst geeft hij aan welk doel op den duur moet worden bereikt. Dit wordt omschreven in zeer abstracte en ambitieuze termen (p. 22-23). Vervolgens draagt hij de verdere uitwerking over aan het maatschappelijk veld. Publieke instellingen, alsmede private organisaties - dat is het verschil met de gelede normstelling in het traditionele bestuursrecht - moeten het doel van de uitbestedende wet concretiseren in door henzelf bepaalde subdoelen en uitwerken in maatstaven voor de beoordeling van de behaalde resultaten (prestatie-indicatoren zoals de tevredenheid van patiënten en het slagingspercentage van studenten, p. 23 en uitgebreider p. 28-31). Als sluitstuk verlangt de wetgever dat deze zelfregelaars 
periodiek rapporteren in hoe verre zij tot dan toe succesvol zijn geweest (p. 23-24).

Westerman signaleert vier aspecten van uitbesteding die van groot belang zijn om de negatieve effecten van dit sturingsmodel te begrijpen. Ten eerste zet deze uitbesteding de zelfregelaars aan tot veelvuldige zelfreplicatie. Het doel van de uitbestedende wet is namelijk veel te abstract om te kunnen meten in hoeverre dat doel is bereikt. Daarom belasten de zelfregelaars op hun beurt graag allerhande interne en externe commissies en stuurgroepen met de taak om weer nieuwe subdoelen en indicatoren te bedenken en elkaar periodiek daarover te rapporteren (p. 48). Wie aan een ziekenhuis of universiteit werkt, ontkomt in die hoedanigheid niet aan protocollen, gedragscodes en vragenlijsten voor enquêtes, zelfevaluatie en visitaties.

Bovendien laat Westerman ook zien dat deze zelfreplicatie een grens kent. De verhouding tussen zelfregelaars en werkvloer is namelijk asymmetrisch. De artsen, verpleegkundigen, docenten, onderzoekers die moeten rapporteren of zij de onderscheiden subdoelen hebben bereikt, mogen niet meer hun eigen doelen bepalen en zelf indicatoren vaststellen. Dat is namelijk de taak geworden van de managers en de bestuurslagen daarboven (p. 53).

Voor de werkvloer komt daar nog bij dat dit sturingsmodel eendimensionaal is. Waar traditionele wetgeving een compromis is tussen de betrokken belangen en verscheidene doelen naast elkaar kan nastreven, kennen uitbestedende wetten ieder slechts één doel. Deze eenzijdigheid is de spil van de analyse van Westerman. Op de werkvloer gelden bij voorbeeld naast elkaar eisen van de zorg- en de arbeidsomstandighedenwetgeving. De individuele werker ziet zich dan ook dikwijls geconfronteerd met onverenigbare subdoelen en prestatie-indicatoren (eveneens p. 53).

Ten slotte laat Westerman zien dat het traditionele ideaal van stabiele wettelijke regels bij deze uitbesteding helemaal uit het zicht is geraakt. De uitbestedende wet is gericht op een abstract doel, dat in de verre toekomst ligt. Dit hoge ambitieniveau, in combinatie met het buitenspel staan van de artsen, docenten en overige werkers op de vloer, leidt ertoe dat de zelfregelaars geen genoegen nemen met een eenmaal bereikt subdoel en de lat telkens weer hoger leggen. De individuele werker ontkomt niet aan benchmarking naar mate van prestaties van concurrerende collega's, aan pas-toe-of-leg-uit en aan steeds weer nieuwe en meer eisende best practices (p. 71). Zo worden procedures belangrijker dan inhoudelijke sturing (p. 73).

Tot zo ver het sturingsmodel zelf. Maar wat betekent het nu voor democratie en rechtspraak? De grootste bedreiging voor de democratie is volgens Westerman het ondoorzichtige conglomeraat van zelfregelaars dat zichzelf heeft weten te schuiven tussen de uitbestedende wet en de werkvloer (p. 76). Zij hoeven geen verantwoording af te leggen aan een vertegenwoordigend lichaam. De ene zelf- 
regelaar draagt taken op aan de andere en houdt het toezicht daarop in eigen hand door die ander ook een rapportageplicht op te leggen (p. 100).

Bij traditionele wetgeving beslecht de rechter geschillen aan de hand van de tekst van de toepasselijke regels. Pas als die niet duidelijk zijn gaat hij zoeken naar de bedoeling van de wetgever. Een uitbestedende wet is daarentegen, zoals gezegd, geen compromis tussen verschillende doelen en kent maar één allesoverheersend abstract doel. Dit laat de rechter geen ruimte om rekening te houden met andere belangen. En als hij het doel van een uitbestedende wet zelf zou gaan concretiseren in een subdoel, treedt hij in de beslissingsruimte van de zelfregelaars (p. 107). Zij zijn de experts die de subdoelen en ook de prestatie-indicatoren moeten vaststellen. Als de rechter deze doelen en indicatoren terzijde zou schuiven treedt hij weer in hun beslissingsruimte (p. 110-111).

Traditionele algemene regels knopen aan bij categorieën, hun algemeenheid dwingt ook tot denken in categorieën in plaats van concrete gevallen (p. 142-146). Traditionele wetgeving heeft vier functies: zij rechtvaardigt beslissingen, reikt handvatten aan voor kritiek, kadert de beschikbare beslissingsruimte in en coördineert gedrag (p. 151-153). Des te breder de voorafgaande afweging van doelen en belang is geweest, des te groter het gezag van het bereikte compromis (p. 154). Westerman benadrukt nog eens dat de uitbestedende wet daarentegen slechts één doel kent. Alleen daarop dienen de zelfregelaars hun subdoelen en indicatoren te richten. Deze subdoelen en indicatoren binden alleen de werkvloer, niet de van de werkers losgezongen zelfregelaars, en kunnen van de ene op de andere dag worden opgeschroefd (p. 155). Het traditionele meeromvattende juridische reservoir van doorslaggevende wettelijke redenen om te handelen of na te laten dreigt uitgeput te raken door uitbesteding van regelgeving (p. 167).

Uitbesteding van regelgeving wordt door Westerman in haar slothoofdstuk getypeerd als doorgeschoten disciplinering (radicalised discipline). Prestaties en doelen zijn belangrijker geworden dan je houden aan stabiele regels. Digitalisering van werkprocessen maakt grenzeloos toezicht en tuchtiging mogelijk (p. 175). De auteur zoekt aansluiting bij de gedachten van Foucault over doel-middel-sturing en neoliberalisme. Maar zij ziet ook verschillen en nieuwe ontwikkelingen. Wat bij deze uitbesteding wordt voorgeschreven, geconcretiseerd en gespecificeerd zijn ambities en resultaten in plaats van gedrag dat tot die resultaten leidt. Verder staan er tussen werk en vrije tijd geen schotten meer (p. 177). Concurrentie is allesoverheersend geworden, veranderlijke best practices hebben de betrouwbare good practices vervangen. Daarbij komt dat positieve sancties als beloningen en subsidies en vooral ook interne en externe naming-and-shaming de overhand hebben gekregen. Negatieve sancties zijn alleen mogelijk als er een onbeweeglijk nulpunt is waaronder de onwenselijkheid van het gedrag vaststaat. Een dergelijke objectiviteit ontbreekt bij best practices of het gemiddelde prestatieniveau (p. 178). Westerman hoopt dat de waarborgen van rechtsbescherming en democratische vormen van verantwoording kunnen worden versterkt en uitgebreid 
zodat deze ook de nieuwe gedecentraliseerde bronnen van uitbestede instrumentele regelgeving gaan omvatten (p. 187).

Het boek is de vrucht van drie decennia nadenken over Outsourcing the Law. Het is een heldere en overtuigende analyse van de risico's van geconditioneerde zelfregulering. Westerman beperkt haar voorbeelden voornamelijk tot Europese kaderrichtlijnen, de medische zorg en het onderwijs. Maar haar bevindingen zijn ook daarbuiten zeer herkenbaar. In het sociaal domein heeft de Centrale Raad van Beroep zijn rol al opgepakt na de decentralisatie van 2015. Gewezen zij op de verstandige jurisprudentie over indicatoren en publiekrechtelijke regelingen (delegatieverbod essentialia, ECLI:NL:CRVB:2017:1803, maar ook ECLI:NL:CRVB: 2019:3206; exceptieve toetsing, ECLI:NL:CRVB:2019:2016) en over maatwerk en rechtszekerheid (stappenplan jeugdhulpverzoeken, ECLI:NL:CRVB:2017:1477; adviseurs zonder wettelijke status, ECLI:NL:CRVB:2018:1113; resultaatsgerichte huishoudelijke ondersteuning, ECLI:NL:CRVB:2018:3241; concretiserende brief zorgaanbieder is besluit B en W, ECLI:NL:CRVB:2017:3633).

Hooguit zou een kanttekening kunnen zijn dat de bevindingen van de auteur hier en daar wel erg absoluut zijn geformuleerd en er misschien toch ook nog wel iets positiefs over uitbesteding van regelgeving valt te zeggen. Mijn enige kritiek is dat zij geen oog heeft voor het schoolvoorbeeld van geslaagde zelfregulering: de rol van de wél representatieve vakbonden, beroepsorganisaties en werkgeversverenigingen bij het bereiken van realistische compromissen in het sociale recht. 